\title{
Ratiometric Detection of Mercury (II) Ions in Living Cells Using Fluorescent Probe Based on Bis(styryl) Dye and Azadithia-15-Crown-5 Ether Receptor
}

\author{
Pavel A. Panchenko ${ }^{1,2, *}$, Anastasija V. Efremenko ${ }^{3,4}$, Alexey V. Feofanov ${ }^{3,4}\left(\right.$, Mariya A. Ustimova ${ }^{1}$, \\ Yuri V. Fedorov ${ }^{1}$ and Olga A. Fedorova ${ }^{1,2}$ \\ 1 Laboratory of Photoactive Supramolecular systems, A.N. Nesmeyanov Institute of Organoelement \\ Compounds of Russian Academy of Sciences (INEOS RAS), 119991 Moscow, Russia; \\ ustimova.maria@yandex.ru (M.A.U.); fedorov@ineos.ac.ru (Y.V.F.); fedorova@ineos.ac.ru (O.A.F.) \\ 2 Department of Technology of Fine Organic Synthesis and Chemistry of Dyes, Dmitry Mendeleev University \\ of Chemical Technology of Russia, 125047 Moscow, Russia \\ 3 Biological Faculty, Lomonosov Moscow State University, 119992 Moscow, Russia; aefr@mail.ru (A.V.E.); \\ avfeofanov@yandex.ru (A.V.F.) \\ 4 Laboratory of Optical Microscopy and Spectroscopy, Shemyakin-Ovchinnikov Institute of Bioorganic \\ Chemistry of Russian Academy of Sciences, 117997 Moscow, Russia \\ * Correspondence: pavel@ineos.ac.ru; Tel.: +7-905-525-07-93
}

\section{check for}

updates

Citation: Panchenko, P.A.; Efremenko, A.V.; Feofanov, A.V.; Ustimova, M.A.; Fedorov, Y.V.; Fedorova, O.A. Ratiometric Detection of Mercury (II) Ions in Living Cells Using Fluorescent Probe Based on Bis(styryl) Dye and Azadithia-15Crown-5 Ether Receptor. Sensors 2021, 21, 470. https://doi.org/10.3390/ s21020470

Received: 15 December 2020 Accepted: 5 January 2021 Published: 11 January 2021

Publisher's Note: MDPI stays neutral with regard to jurisdictional clai$\mathrm{ms}$ in published maps and institutional affiliations.

Copyright: (C) 2021 by the authors. Licensee MDPI, Basel, Switzerland. This article is an open access article distributed under the terms and conditions of the Creative Commons Attribution (CC BY) license (https:// creativecommons.org/licenses/by/ $4.0 /)$.

\begin{abstract}
Bis(styryl) dye 1 bearing N-phenylazadithia-15-crown-5 ether receptor has been evaluated as a ratiometric fluorescent chemosensor for mercury (II) ions in living cells. In aqueous solution, probe 1 selectively responds to the presence of $\mathrm{Hg}^{2+}$ via the changes in the emission intensity as well as in the emission band shape, which is a result of formation of the complex with 1:1 metal to ligand ratio (dissociation constant $0.56 \pm 0.15 \mu \mathrm{M}$ ). The sensing mechanism is based on the interplay between the RET (resonance energy transfer) and ICT (intramolecular charge transfer) interactions occurring upon the UV/Vis (380 or $405 \mathrm{~nm}$ ) photoexcitation of both styryl chromophores in probe 1 . Bio-imaging studies revealed that the yellow $(500-600 \mathrm{~nm})$ to red $(600-730 \mathrm{~nm})$ fluorescence intensity ratio decreased from $4.4 \pm 0.2$ to $1.43 \pm 0.10$ when cells were exposed to increasing concentration of mercury (II) ions enabling ratiometric quantification of intracellular $\mathrm{Hg}^{2+}$ concentration in the $37 \mathrm{nM}-1 \mu \mathrm{M}$ range.
\end{abstract}

Keywords: $\mathrm{Hg}^{2+}$; ratiometric sensor; fluorescence imaging; resonance energy transfer; intramolecular charge transfer; styryl dye; crown ether; living cells; human lung adenocarcinoma A549 cells

\section{Introduction}

Construction of fluorescent chemosensors for heavy and transition metal cations are in the focus of current research [1-3]. Among various cations, $\mathrm{Hg}^{2+}$ is well-known for its high toxicity and capacity for bioaccumulation. $\mathrm{Hg}^{2+}$ ions can be released in the environment along with the effluent or as a result of atmospheric oxidation of mercury vapor [4]. Further bioaccumulation by microorganisms in water transforms $\mathrm{Hg}^{2+}$ to methylmercury, a form that can be easily included into the food chain $[5,6]$. Upon consumption by humans, this toxin may cause serious health disorders [7]. Given that mercury and its compounds are extensively employed in industry and agriculture [8], reliable and sensitive probes for the detection of $\mathrm{Hg}^{2+}$ in biological systems are in demand.

To date, a large number of fluorescent chemosensors capable of tracing of low concentrations of $\mathrm{Hg}^{2+}$ in aqueous solutions has been reported. Most of them exhibit changes in the fluorescent characteristics due to switching of the photoinduced electron transfer (PET) process between the receptor and chromophore upon complexation with $\mathrm{Hg}^{2+}$. Such systems provide detection of analyte via enhancement $[9,10]$ or quenching $[11,12]$ of the emission intensity without changes in the shape and maximum position of a fluorescence 
spectrum. At the same time, intensity responsive sensors have limited applicability for $\mathrm{Hg}^{2+}$ detection in vivo, in particular, in living cells, because their intracellular fluorescence is affected by concentrations of both $\mathrm{Hg}^{2+}$ and sensor itself. Analytics in vivo requires ratiometric sensors, which change fluorescence spectrum shape and/or maximum upon complexation with $\mathrm{Hg}^{2+}$ [13]. Dual-wavelength measurement of fluorescence with ratiometric sensors obviates an influence of sensor concentration on the $\mathrm{Hg}^{2+}$ detection and facilitates $\mathrm{Hg}^{2+}$ quantification both in vivo and in vitro.

Ratiometric fluorescent response to metal cations can be realized by means of several photophysical mechanisms: intramolecular charge transfer (ICT) [14,15], resonance energy transfer (RET) between two chromophore fragments [16-18], excimer/exciplex formation [19], or excited state intramolecular proton transfer (ESIPT) [20]. Despite the obvious advantage, the number of ratiometric fluorescent probes for $\mathrm{Hg}^{2+}$ cation is rather limited even for in vitro analysis, and most of them exploit $\mathrm{Hg}^{2+}$-induced spyrolactam ring opening of rhodamine dyes, which act as energy acceptor chromophores [21-23]. Alternatively, we have recently demonstrated that coordination of metal ions $\left(\mathrm{Na}^{+}, \mathrm{Li}^{+}, \mathrm{Mg}^{2+}, \mathrm{Ca}^{2+}\right.$, $\left.\mathrm{Ba}^{2+}, \mathrm{Hg}^{2+}, \mathrm{Ag}^{+}\right)$and $\mathrm{H}^{+}$with either azacrown or oxacrown receptors of bis(styryl) dye 1 (Scheme 1) in an organic solvent (acetonitrile) allows one to modulate the RET efficiency between the photoactive styryl subunits, thus producing a distinct ratiometric fluorescent response in each case [24,25]. Herein, we report that the ion complexation profile of dye $\mathbf{1}$ in aqueous environment is characterized by an enhanced selectivity to $\mathrm{Hg}^{2+}$ ions, and complex formation leads to changes in its emission spectrum shape and intensity. Compound $\mathbf{1}$ is demonstrated to penetrate into living cells and can be used for the ratiometric detection of $\mathrm{Hg}(\mathrm{II})$ in vivo. The concentration range of $\mathrm{Hg}^{2+}$ ion detection in cells $(37 \mathrm{nM}-1 \mu \mathrm{M})$ provided by dye $\mathbf{1}$ is suitable for analytical applications. As a supporting study useful for the analysis of sensor behavior in biological systems, we also present the investigation of metal cation binding properties of dyad 1 and monochromophoric compounds 2 and 3 (Scheme 1) in an aqueous solution.
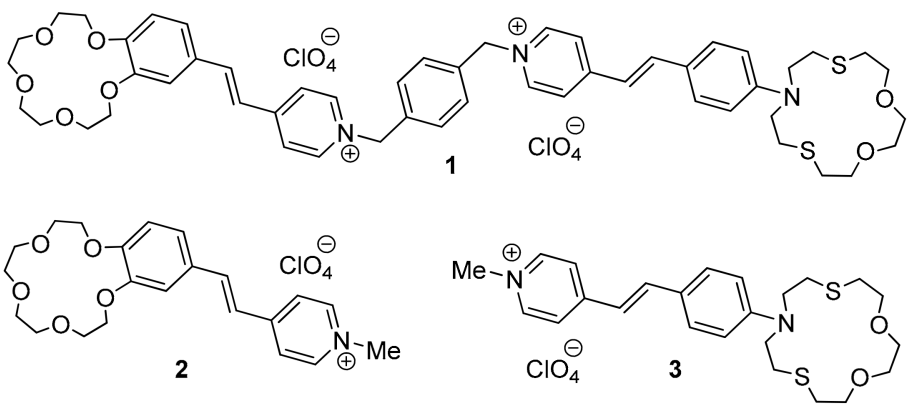

Scheme 1. Chemical structure of compounds 1, 2, and 3.

\section{Materials and Methods}

\subsection{Reagents for Spectroscopic Studies}

The bis(styryl) dye 1 was obtained by condensation of the formyl derivatives of benzo15-crown-5 and $N$-phenylazadithia-15-crown-5 ethers with $\gamma$-picoline and subsequent quaternization of the intermediate styryl(pyridine) species with 1,4-bis(bromomethyl)benzene [24]. The parent mono-chromophoric dyes 2 and 3 were synthesized according to published protocols [26,27]. Acetate buffer solution was prepared with deionized water $(18.2 \mathrm{M} \Omega \cdot \mathrm{cm})$. Perchlorates of $\mathrm{Cu}^{2+}, \mathrm{Zn}^{2+}, \mathrm{Pb}^{2+}, \mathrm{Cd}^{2+}, \mathrm{Ni}^{2+}, \mathrm{Fe}^{2+}, \mathrm{Ca}^{2+}$, and $\mathrm{Mg}^{2+}$ were dissolved in MeCN (HPLC grade) and then used in spectroscopic studies. $\mathrm{Hg}\left(\mathrm{ClO}_{4}\right)_{2}$ was dissolved in water and stabilized by the addition of 0.5 equivalents (equiv.) of $\mathrm{HClO}_{4}$. The exact concentration of $\mathrm{Hg}\left(\mathrm{ClO}_{4}\right)_{2}$ was determined by complexometric titration using EDTA and xylenol orange as an indicator. Stock solutions of compounds 1, 2, and 3 for the steady-state optical measurements and for the determination of stability constants were prepared with HPLC grade acetonitrile and were of a concentration of $5 \times 10^{-4} \mathrm{M}$. Before collecting 
the spectra, these solutions $(100 \mu \mathrm{L})$ were added to acetate buffer solution or pure water $(2.5 \mathrm{~mL})$. The MeCN content in the resulting mixtures was 3.8 vol. \%.

\subsection{Steady-State Optical Measurements in Solution}

Absorption and fluorescence spectra of the compounds were recorded in air-saturated solutions at ambient temperature with a Cary 300 spectrophotometer (Agilent Technologies, Victoria, Australia) and Eclipse Cary spectrofluorimeter (Agilent Technologies, Victoria, Australia). All measured fluorescence spectra were corrected for the nonuniformity of detector spectral sensitivity. Coumarin 481 in acetonitrile (fluorescence quantum yield $\left.\varphi^{\mathrm{fl}}=0.08\right)$ [28] was used as a reference for the fluorescence quantum yield measurements.

\subsection{Determination of Complex Stability Constants}

Complex formation of ligands $\mathbf{1}$ and $\mathbf{3}$ with $\mathrm{Hg}^{2+}$ was studied in aqueous solution by spectrophotometric and spectrofluorometric titration [29,30]. Compound $\mathbf{1}$ of known concentration in acetate buffer $(\mathrm{pH} 6.0,10 \mathrm{mM})$ was titrated with a solution of mercury (II) perchlorate. After addition of each aliquot of $\mathrm{Hg}\left(\mathrm{ClO}_{4}\right)_{2}$ absorption or fluorescence spectrum was recorded, and the stability constants of the complexes were determined using the SPECFIT / 32 program (Spectrum Software Associates, West Marlborough, MA, USA). The following equilibria were considered in the fitting of experimental data:

$$
\begin{gathered}
\mathrm{L}+\mathrm{Hg}^{2+} \rightleftarrows(\mathrm{L}) \cdot \mathrm{Hg}^{2+} \\
2 \mathrm{~L}+\mathrm{Hg}^{2+} \rightleftarrows(\mathrm{L})_{2} \cdot \mathrm{Hg}^{2+}
\end{gathered}
$$

In doing so, it was found that the experimental data corresponded to the theoretical ones if only the Equation (1) was taken into account, and the formation of the complex with composition of 2:1 was assumed to be negligible.

\subsection{Cells and Their Treatment}

Human lung adenocarcinoma cells A549 were obtained from Ivanovsky institute of Virology (Russia) and grown in DMEM-Eagle medium supplemented with L-glutamine $(2 \mathrm{mM})$ and $10 \%$ fetal bovine serum (FBS), abbreviated below as a complete medium. Cells were subcultured two times per week $\left(37^{\circ} \mathrm{C}, 5 \% \mathrm{CO}_{2}\right)$.

For microscopic experiments, cells were seeded on a round cover glasses placed in 24 -well plates and grown for $24 \mathrm{~h}$. Sowing density was $2 \times 10^{5}$ cells per ml. To study cellular accumulation and distribution of $\mathbf{1 - 3}$ as well as uptake kinetics of $\mathbf{1}$, cells were incubated (5-60 min, $37^{\circ} \mathrm{C}$ ) with 1-3 $(10 \mu \mathrm{M})$ added from $1 \mathrm{mM}$ dimethylsulfoxide (DMSO) solutions in a complete medium, washed twice with Hanks' solution, and subjected to microscopy analysis. Retention of $\mathbf{1}$ in cells was studied for cells pre-incubated with $\mathbf{1}$ $(10 \mu \mathrm{M})$ for $30 \mathrm{~min}$, placed in the fresh medium (without 1$)$ for different $(0-2.5 \mathrm{~h})$ periods of time, and recorded with confocal laser scanning microscope at the identical parameters of measurements. For the study of intracellular complexation of $\mathrm{Hg}^{2+}$ with $\mathbf{1}$ and $\mathbf{3} \mathrm{or} \mathrm{Cu}^{2+}$ and $\mathrm{Pb}^{2+}$ with 1 , the cells were pre-incubated $(15 \mathrm{~min})$ with $\mathrm{Hg}\left(\mathrm{ClO}_{4}\right)_{2}$ at 2-50 $\mu \mathrm{M}$ and $\mathrm{Pb}\left[\mathrm{ClO}_{4}\right]_{2}$ or $\mathrm{Cu}\left[\mathrm{ClO}_{4}\right]_{2}$ at $2 \mu \mathrm{M}-1 \mathrm{mM}$. Next, the cells were washed twice with Hanks' solution, incubated (20 min) with 1 or 3 at $10 \mu \mathrm{M}$, washed twice with Hanks' solution, and subjected to microscopy measurements. It should be mentioned that the used regime of incubation of A549 cells with compound $\mathbf{1}(10 \mu \mathrm{M})$ and $\mathrm{Hg}\left(\mathrm{ClO}_{4}\right)_{2}(2-20 \mu \mathrm{M})$ did not induce death of cells as verified by the live/dead cell assay based on differential ability of Hoechst 33,342 and propidium iodide (PI) to penetrate in living and dead cells (for details see Section S5 of Supplementary Materials and Figure S20). Dead cells (15-17\%) appeared at $50 \mu \mathrm{M} \mathrm{Hg}\left(\mathrm{ClO}_{4}\right)_{2}$ as confirmed by the Hoechst 33342/PI assay. They were easily recognized due to their round shape and excluded from the measurements.

Cytotoxicity of compound 1 and $\mathrm{Hg}\left(\mathrm{ClO}_{4}\right)_{2}$ for A549 cells was additionally estimated after $24 \mathrm{~h}$ incubation of cells with 1 or $\mathrm{Hg}\left(\mathrm{ClO}_{4}\right)_{2}$ separately, using MTT assay as described in Section S5 of Supplementary Materials. The highest concentration of $\mathbf{1}$ used in the 
presented studies $(10 \mu \mathrm{M})$ did not affect the cell growth (Figure S21b). As for $\mathrm{Hg}\left(\mathrm{ClO}_{4}\right)_{2}$, survival of cells decreased at $\mathrm{Hg}\left(\mathrm{ClO}_{4}\right)_{2}$ concentrations higher $2.5 \mu \mathrm{M}$, and the effect achieved ca. $30 \%$ at $20 \mu \mathrm{M}$ (Figure S21a).

\subsection{Confocal Microscopy Measurements}

Fluorescence microscopy studies of 1-3 were performed with the LSM-710 confocal laser scanning microscope (Carl Zeiss AG, Oberkochen, Germany). The confocal fluorescent images were obtained with the $\alpha$ Plan-Apochromat $100 \times / 1.4$ oil-immersion objective at $0.3 \mu \mathrm{m}$ lateral and $1.5 \mu \mathrm{m}$ axial resolution. Studying the intracellular distribution of $\mathbf{1}$ and 2 or the kinetics of cellular accumulation of $\mathbf{1}$ in cells, fluorescence was excited at the $405 \mathrm{~nm}$ wavelength, and emission was registered in the $450-730 \mathrm{~nm}$ spectral range for 1 or in the $420-650 \mathrm{~nm}$ range for 2 . The $488 \mathrm{~nm}$ excitation wavelength and the $500-730 \mathrm{~nm}$ detection spectral range were used in the studies of intracellular distribution of 3 .

For a ratiometric analysis (intracellular complexation of $\mathbf{1}$ with $\mathrm{Hg}^{2+}, \mathrm{Cu}^{2+}$, or $\mathrm{Pb}^{2+}$ ), fluorescence was excited at 405 or $488 \mathrm{~nm}$ wavelength and recorded simultaneously in the 500-600 and 600-730 nm spectral ranges. Alternatively, fluorescence of 1 was excited at the $405 \mathrm{~nm}$ wavelength and registered simultaneously in the 450-550 and 550-730 nm spectral ranges (see Supplementary Information). Intracellular complexation of 3 with $\mathrm{Hg}^{2+}$ was studied at the $488 \mathrm{~nm}$ excitation wavelength, and emission was registered simultaneously in the 500-600 and 600-730 nm spectral ranges.

Intracellular fluorescence spectra of compounds 1-3 were recorded using the spectral mode of confocal image measurements. Fluorescence was excited at $405 \mathrm{~nm}$ wavelength and recorded in the 420-730 or 420-650 nm spectral ranges with a spectral resolution of $5 \mathrm{~nm}$ for $\mathbf{1}$ or 2 , respectively. Fluorescence was excited at $488 \mathrm{~nm}$ wavelength and recorded in the 500-725 nm spectral range with a spectral resolution of $5 \mathrm{~nm}$ for $\mathbf{1}$ and 3 .

\section{Results and Discussion}

\subsection{Spectral Characteristics of the Compounds}

Spectroscopic and $\mathrm{Hg}^{2+}$-binding properties of probe $\mathbf{1}$ and its constituents $\mathbf{2}$ and $\mathbf{3}$ were studied in aqueous solution (Figure 1, Table 1). All experiments were carried out at $\mathrm{pH} 6.0$ (acetate buffer, $0.01 \mathrm{M}$ ), which, on the one hand, is rather close to slightly acidic environment inside A549 cells [31] (these cells were used in cellular experiments below), and on the other hand, excludes protonation at the azacrown ether nitrogen atom and related spectral shifts. Protonation at nitrogen atom of $\mathrm{N}$-phenylazadithia-15-crown-5 ether receptor in water solution occurs at $\mathrm{pH}$ values lower than 4.0 , as it has been shown for the previously synthesized 4-amino- $N$-aryl-1,8-naphthalimide [32,33], where the $\mathrm{N}$-phenylazadithia-15-crown-5 ether receptor is present as an $\mathrm{N}$-aryl group and not conjugated with the chromophoric part of the molecule. In this sense, probe 1 should be even less basic due to delocalization of the amine nitrogen lone pair electrons into the $\pi$-system of positively charged styryl(pyridinium) fragment. As Figure 1a,b shows, maxima of absorption and emission spectra of compound 2 are at 380 and $540 \mathrm{~nm}$, respectively, whereas corresponding maxima of 3 are centered at 460 and $610 \mathrm{~nm}$. From these observations, one can notice that considerable part of the emission spectrum of $\mathbf{2}$ overlaps with the long-wavelength absorption band of $\mathbf{3}$ (see Figure S2 for the graphical representation). Regarding dye 1, such an overlap means that RET from the excited donor $O$-chromophore (benzo-15-crown-5-containing fragment) to acceptor $\mathrm{N}$-chromophore (azadithia-15-crown-5-containing fragment) could proceed effectively. 


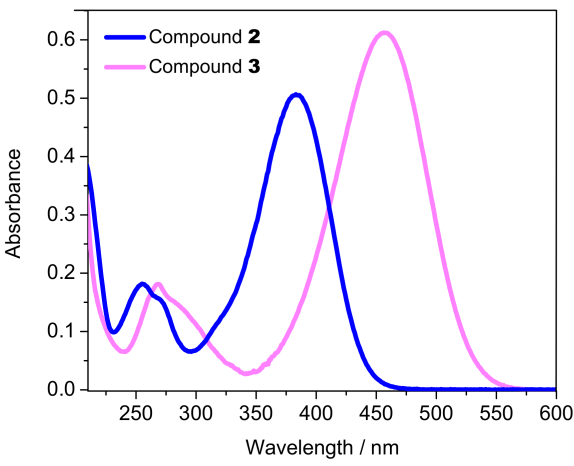

(a)

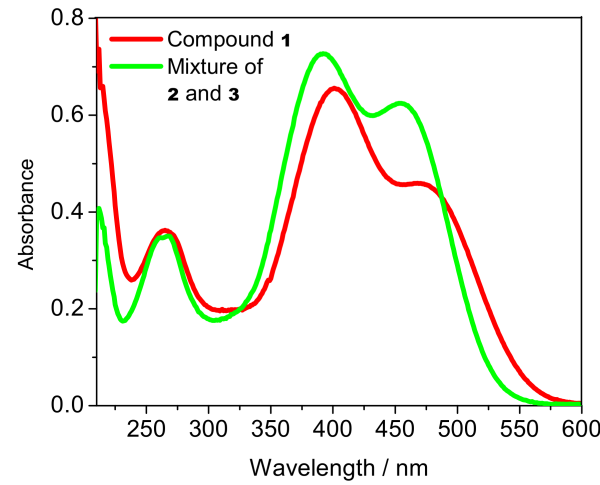

(c)

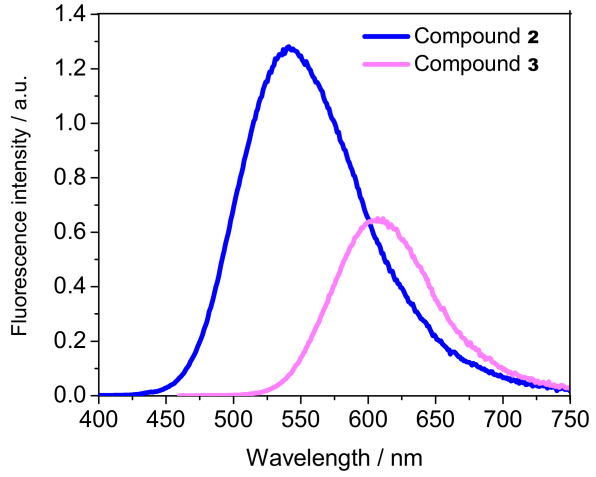

(b)

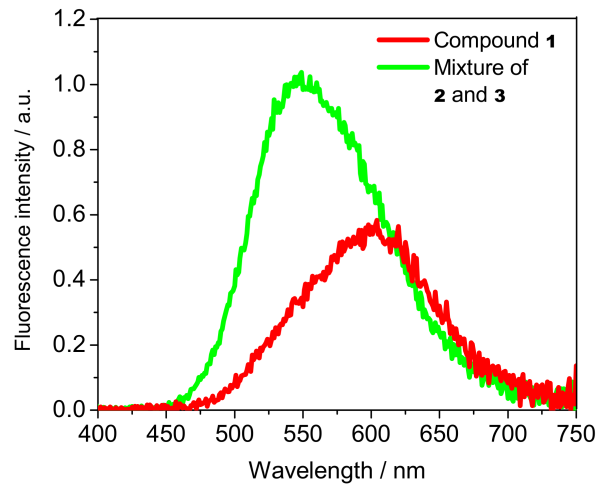

(d)

Figure 1. Absorption $(\mathbf{a}, \mathbf{c})$ and fluorescence $(\mathbf{b}, \mathbf{d})$ spectra of compounds $\mathbf{1}(\mathbf{c}, \mathbf{d}), \mathbf{2}(\mathbf{a}, \mathbf{b}), \mathbf{3}(\mathbf{a}, \mathbf{b})$, and equimolar mixture of 2 and $\mathbf{3}(\mathbf{c}, \mathbf{d})$ in water at pH 6.0 (acetate buffer, $10 \mathrm{mM}$ ). Concentrations of all compounds $20 \mu \mathrm{M}$. Excitation wavelengths $\lambda_{\mathrm{ex}}$ were $450 \mathrm{~nm}$ for 3 and $380 \mathrm{~nm}$ for 1, 2, and mixture of 2 and 3.

Table 1. Spectral characteristics of compounds 1,2 , and 3 and stability constants of their complexes ${ }^{a}$ with $\mathrm{Hg}^{2+}$ in water at pH 6.0 (10 mM acetate buffer) ${ }^{a}$.

\begin{tabular}{ccccccc}
\hline \multirow{2}{*}{ Species } & $\lambda_{\text {max }}^{\text {abs }} / \mathbf{n m}$ & $\varepsilon_{\lambda} / \mathbf{M}^{-\mathbf{1}} \cdot \mathbf{c m}^{-1}$ & $\lambda_{\text {max }}^{f l}\left(\lambda_{\text {ex }}\right) / \mathbf{n m}$ & $\boldsymbol{\varphi}^{f l}$ & $\begin{array}{c}\text { Spectrophotometric } \\
\text { Titration }\end{array}$ & $\begin{array}{c}\text { Spectrofluorometric } \\
\text { Titration }\end{array}$ \\
\hline $\mathbf{1}$ & $402 ; 469$ & 32,$700 ; 22,950$ & $603(380)$ & 0.015 & - & - \\
\hline$(\mathbf{1}) \cdot \mathrm{Hg}^{2+}$ & 395 & 40,970 & $581(380)$ & 0.041 & $6.27 \pm 0.12$ & - \\
\hline $\mathbf{2}$ & 384 & 25,300 & $541(380)$ & 0.029 & - & - \\
\hline $\mathbf{3}$ & 457 & 30,650 & $607(405)$ & 0.012 & - & -11 \\
\hline$(3) \cdot \mathrm{Hg}^{2+}$ & 380 & 18,390 & $571(405)$ & 0.052 & $6.03 \pm 0.06$ & $6.05 \pm 0.06$ \\
\hline
\end{tabular}

${ }^{a}$ Absorption $\left(\lambda_{\max }^{\mathrm{abs}}, \varepsilon_{\lambda}\right)$ and emission $\left(\lambda_{\max }^{\mathrm{fl}}, \varphi^{\mathrm{fl}}\right)$ characterisctics of the complexes were found from their absorption and emission spectra calculated using SPECFIT/32 program (see Figures S3 and S4).

Absorption spectrum of compound 1 (Figure 1c) contains two peaks in the long wavelength region at 402 and $469 \mathrm{~nm}$, which are characteristic of both individual dyes 2 and 3. Some red shift $(10-15 \mathrm{~nm})$ in the peak positions on going from equimolar mixture of $\mathbf{2}$ and $\mathbf{3}$ to dye $\mathbf{1}$ can be explained by the increased polarization of the chromophores and, hence, the more pronounced ICT interaction, resulting from proximity of two positive charges in the structure of $\mathbf{1}$.

Upon excitation by $380 \mathrm{~nm}$ light, which is mostly absorbed by O-chromophore, equimolar mixture of 2 and 3 exhibited the emission band at $548 \mathrm{~nm}$ (Figure 1d), similar to that in the spectrum of $\mathbf{2}$ (Figure 1b). The spectrum of $\mathbf{1}$ recorded under the same conditions 
consisted of the red-shifted signal $\left(\lambda_{\max }^{\mathrm{fl}} 603 \mathrm{~nm}\right)$ corresponding to the $N$-chromophore fluorescence. This result indicates preservation of RET in the compound $\mathbf{1}$ in slightly acidic aqueous environment. Noteworthily, comparison of the spectra of $\mathbf{1}$ and $\mathbf{3}$ presented in Figure $1 \mathrm{~b}, \mathrm{~d}$ shows that the short wavelength part of the emission band of $\mathbf{1}$ (Figure $1 \mathrm{~d}$ ) is broadened to some extent by the residual fluorescence of the donor. Using the emission intensities at $490 \mathrm{~nm}$ where the acceptor chromophore does not emit light (see Figure 1b) for compound $\mathbf{1}(I)$ and equimolar mixture of $\mathbf{2}$ and $\mathbf{3}\left(I_{0}\right)$, the energy transfer efficiency was calculated to be as high as $0.84(84 \%)$ according to the Equation (3) [34]:

$$
\Phi_{\mathrm{RET}}=1-\frac{I}{I_{0}}
$$

A rather close value of $\Phi_{\mathrm{RET}}(91 \%)$ was obtained using the theoretical calculations by the Förster model [34] (for details see Supplementary Information).

\subsection{Complexation with Metal Cations in Solution}

Next, we proceeded to the complex formation experiments. In contrast to previously reported data obtained in acetonitrile [24,25], addition of $\mathrm{Cu}^{2+}, \mathrm{Zn}^{2+}, \mathrm{Pb}^{2+}, \mathrm{Cd}^{2+}, \mathrm{Ni}^{2+}, \mathrm{Fe}^{2+}$, $\mathrm{Ca}^{2+}$, and $\mathrm{Mg}^{2+}$ cations did not result in significant changes in the absorption and emission spectra of probe 1 in aqueous solution (Figures S5-S12). In the same conditions, an addition of gradual amounts of $\mathrm{Hg}^{2+}$ decreased dramatically the absorbance of $\mathbf{1}$ at $470 \mathrm{~nm}$ with a concomitant growth of the intensity of the short wavelength band (Figure 2a). The $\mathrm{Hg}^{2+}$ induced changes in the fluorescence spectrum of $\mathbf{1}$ obtained under the excitation at $380 \mathrm{~nm}$ consisted in an enhancement of the emission signal, which was also found to be blue shifted with respect to the parent position (Figure $2 b$ ). The latter observation allows one to consider dye 1 as a ratiometric probe (for more clarity see the influence of $\mathrm{Hg}^{2+}$ on the normalized emission spectrum, Figure S13). The spectra obtained at different concentrations of $\mathrm{Hg}^{2+}$ cation were consistent with the formation of the complex with 1:1 metal to ligand ratio in aqueous solution and were applied for the calculation of the complex stability constant (see Table 1 and Section 2.3 for details). The competition experiments were also conducted (Figure S14). In a typical procedure, the emission spectrum was measured before and after the addition of other ions (5 equiv.) to the solution of $\mathbf{1}\left(2 \cdot 10^{-5} \mathrm{M}\right)$ containing $\mathrm{Hg}^{2+}$ (1 equiv.). It was found that the presence of $\mathrm{Cu}^{2+}, \mathrm{Zn}^{2+}, \mathrm{Pb}^{2+}, \mathrm{Cd}^{2+}, \mathrm{Ni}^{2+}, \mathrm{Fe}^{2+}, \mathrm{Ca}^{2+}$, and $\mathrm{Mg}^{2+}$ did not interfere with $\mathrm{Hg}^{2+}$ sensing.

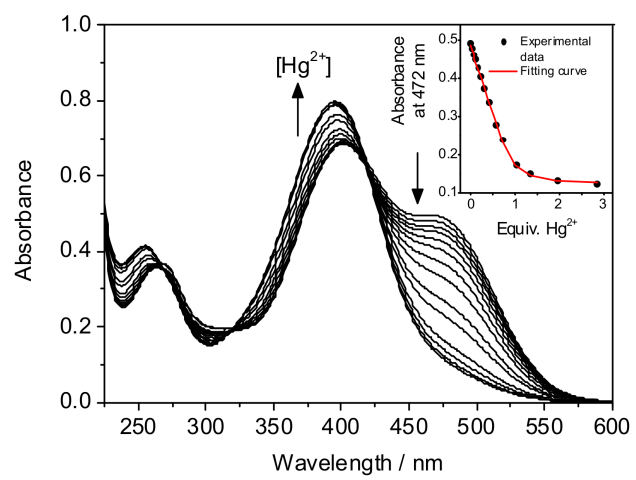

(a)

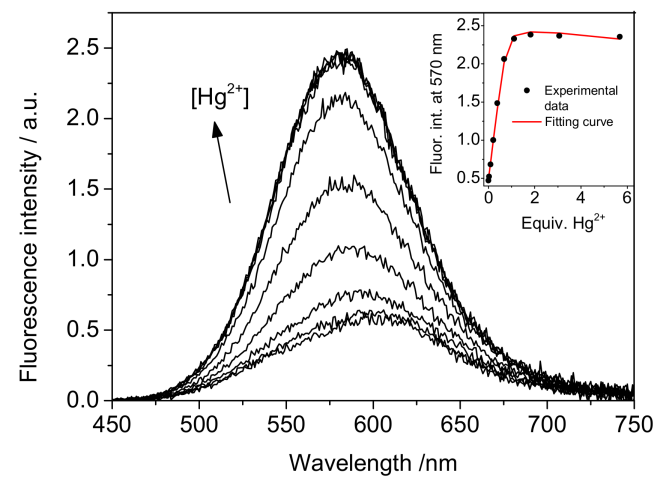

(b)

Figure 2. Changes in the absorption (a) and fluorescence (b) spectra of compound $\mathbf{1}\left(2 \times 10^{-5} \mathrm{M}\right)$ upon addition of aliquots of $\mathrm{Hg}\left[\mathrm{ClO}_{4}\right]_{2}$ in water at $\mathrm{pH} 6.0$ (acetate buffer, $0.01 \mathrm{M}$ ). Excitation wavelength was $380 \mathrm{~nm}$. The upper inserts show the absorbance at $472 \mathrm{~nm}$ (a) or fluorescence intensity at $570 \mathrm{~nm}$ (b) versus equivalents of $\mathrm{Hg}^{2+}$ added.

To explain the observed spectral effects, we further evaluated the influence of $\mathrm{Hg}^{2+}$ addition on the spectroscopic properties of the monochromophoric derivatives 2 and 3 . In the case of oxacrown compound 2, no changes in the position and intensity of the long 
wavelength absorption and emission bands were found (Figure S17), indicating that the energy donor chromophore in $\mathbf{1}$ is not involved in $\mathrm{Hg}^{2+}$ coordination. The presence of benzo-15-crown-5 ether group in the structure of probe $\mathbf{1}$ is supposed to increase its solubility in aqueous medium. As we have also found, this group is capable to bind with $\mathrm{Na}^{+}$and $\mathrm{K}^{+}$cations at concentrations higher than $1 \mathrm{mM}$ in water (see the changes in the absorption and fluorescence spectra of $\mathbf{1}$ upon addition of $\mathrm{Na}^{+}$and $\mathrm{K}^{+}$, Figures S15 and S16). However, sensing of $\mathrm{Hg}^{2+}$ with 1 apparently copes with such complexation as the $0.01 \mathrm{M}$ acetate buffer solution (the medium used in complex formation studies) was prepared using $\mathrm{CH}_{3} \mathrm{COONa}$ and also contained high $\mathrm{Na}^{+}$concentration.

Azacrown ether derivative 3 demonstrated a pronounced $(77 \mathrm{~nm})$ blue shift in the absorption spectrum (see Table 1 and Figure S18a) with a new band of the complex (3) $\cdot \mathrm{Hg}^{2+}$ arising at $380 \mathrm{~nm}$ and isosbestic point at $408 \mathrm{~nm}$. Under the excitation at $405 \mathrm{~nm}$, where the absorption values of the ligand 3 and (3) $\cdot \mathrm{Hg}^{2+}$ are rather close, the emission spectrum of 3 showed an increase in the intensity and a shift of $\lambda_{\max }^{\mathrm{fl}}$ to a short wavelength region (Figure S18b). Based on the analysis of the presented data, the fluorescence enhancement can be ascribed to a higher fluorescence quantum yield of (3) $\cdot \mathrm{Hg}^{2+}$ complex (Table 1), whereas the blue shift could be a result of a reduced ICT interaction between the donor azacrown ether nitrogen atom coordinated with the cation and the acceptor $N$-alkylpyridinium moiety.

Bearing in mind these points, one can assume that the changes in the absorption spectrum of 1 in the presence of $\mathrm{Hg}\left[\mathrm{ClO}_{4}\right]_{2}$ are related only with the hypsochromic shift of the $N$-chromophore ICT band caused by the coordination of azadithia-15-crown-5 ether receptor with mercury (II) cation. The nature of the fluorescence response of $\mathbf{1}$, however, appears to be more intricate. Excitation wavelength $380 \mathrm{~nm}$ used for spectrofluorometric titration corresponds to the absorption maximum of the complex of $N$-chromophore with $\mathrm{Hg}^{2+}$ (Table 1). This means that the observed fluorescence enhancement (Figure 2b) is in part related to the direct excitation of the $N$-chromophore fragment in complex $(\mathbf{1}) \cdot \mathrm{Hg}^{2+}$, the concentration of which increases during the titration experiment. At the same time, the wavelength $380 \mathrm{~nm}$ is close to $\lambda_{\max }^{\text {abs }}$ of the oxacrown derivative 2 (Table 1), which allows us to assume some contribution from the $O$-chromophore fluorescence in the emission band of (1) $\cdot \mathrm{Hg}^{2+}$. Indeed, the hypsochromic shift observed for compound 3 upon binding with $\mathrm{Hg}^{2+}$ leads to a decrease in the overlap of its absorption band with emission spectrum of 2 (Figure S2). According to the calculations by the Förster theory (see Supplementary Information), this could reduce the $\Phi_{\text {RET }}$ value from $84 \%$ (for the free ligand 1 , see above) to $31 \%$ (for $(\mathbf{1}) \cdot \mathrm{Hg}^{2+}$ ). Hence, a considerable part of the excited donor fragments in $(\mathbf{1}) \cdot \mathrm{Hg}^{2+}$ may deactivate radiatively, thereby contributing to the overall spectrum. In contrast to the free ligand 1, the short wavelength part of (1) $\cdot \mathrm{Hg}^{2+}$ fluorescence band was not broadened, because of the close $\lambda_{\max }^{\mathrm{fl}}$ values for $\mathrm{O}$-chromophore and complexed $N$-chromophore emission (compare $\lambda_{\max }^{\mathrm{fl}}$ for compound $\mathbf{2}$ and $(\mathbf{1}) \cdot \mathrm{Hg}^{2+}$ in Table 1).

\subsection{Cellular Imaging of the Studied Compounds}

We investigated applicability of 1 for the fluorescent imaging of $\mathrm{Hg}^{2+}$ in living cells and utilized compounds 2 and $\mathbf{3}$ to clarify intracellular properties of $\mathbf{1}$. Using confocal laser scanning microscopy (CLSM), it was revealed that 1-3 penetrated in the human lung adenocarcinoma A549 cells and accumulated in cytoplasm (Figure 3). At the optimized excitation and detection conditions, compounds $\mathbf{1}$ and $\mathbf{3}$ fluoresced brightly in cells, while cellular fluorescence of $\mathbf{2}$ was weak. The patterns of intracellular distribution of 1-3 were found to be different. Accumulation in vesicular structures of a submicron size and diffuse staining of cytoplasm were observed for $\mathbf{1}$ (Figure 3a). Compound $\mathbf{2}$ demonstrated diffuse staining of cytoplasm (Figure $3 b$ ). Compound 3 accumulated in elongated structures forming a complex network (Figure 3c), whose morphology is typical for mitochondria. 
I

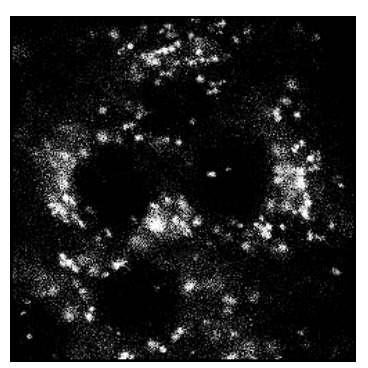

(b)

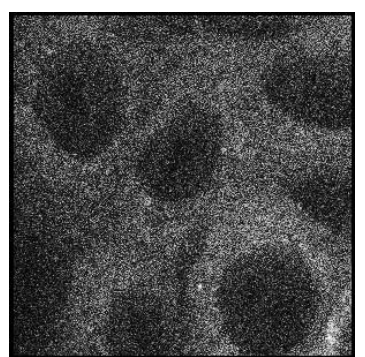

(c)

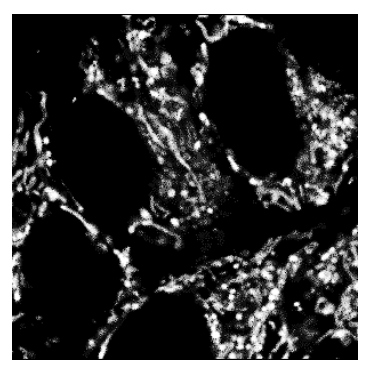

II

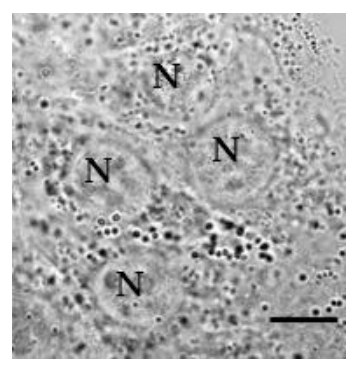

(d)

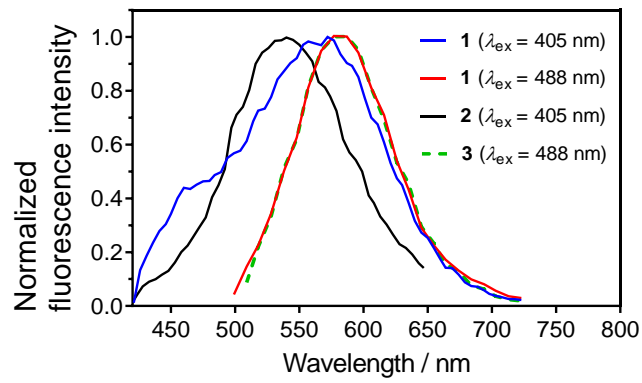

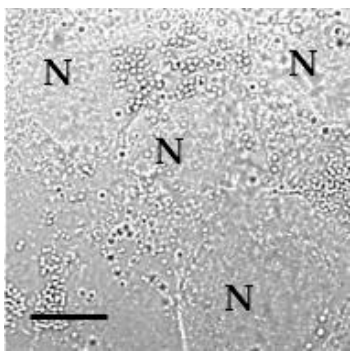

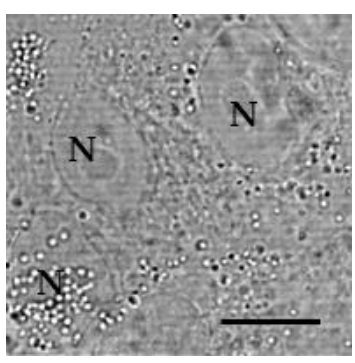

Figure 3. Confocal fluorescence images (a-c) and fluorescence spectra (d) of 1-3 in A549 cells. (a-c) Typical intracellular distributions (column I) of $\mathbf{1}$ (a), $\mathbf{2}$ (b), and $\mathbf{3}$ (c) and corresponding transmitted light images of cells (column II). Bar represents $10 \mu \mathrm{m}$. N marks a nucleus. Cells were incubated with 1-3 (10 $\mu \mathrm{M})$ for $30 \mathrm{~min}$. (d) Typical intracellular fluorescence spectra of $\mathbf{1}, \mathbf{2}$, and 3 normalized to the maximum. At $\lambda_{\mathrm{ex}}=488 \mathrm{~nm}$, spectra of $\mathbf{1}$ and $\mathbf{3}$ coincide in a shape.

To clarify an origin of organelles accumulating compounds $\mathbf{1}$ and $\mathbf{3}$, a colocalization analysis of vital fluorescent probes for particular organelles and the studied compounds was performed. A study of colocalization of 3 and rhodamine 123, a selective fluorescent probe of mitochondria, confirmed mitochondrial accumulation of 3 in A549 cells (Figure S22). The vesicles stained with 1 were demonstrated to be different from lipid droplets, i.e., cellular organelles that store neutral lipids (Figure S23). Using chlorin $e_{6}$ derivative (see Figure S24 for the structure), which was previously shown to accumulate in lysosomes [35], it was revealed that compound $\mathbf{1}$ is localized in lysosomes (Figure S25).

Intracellular fluorescence spectra of compounds 1-3 were analyzed using the spectral mode of confocal image measurements. At excitation wavelength $\lambda_{\mathrm{ex}}=488 \mathrm{~nm}$, compounds 1 and 3 have very similar intracellular spectra with a maximum at ca. $584 \mathrm{~nm}$ (Figure 3d). Intracellular fluorescence spectrum of $2\left(\lambda_{\mathrm{ex}}=405 \mathrm{~nm}\right)$ has a maximum at ca. $543 \mathrm{~nm}$. Fluorescence spectra of compounds $1\left(\lambda_{\mathrm{ex}}=488 \mathrm{~nm}\right), \mathbf{2}$, and 3 were not noticeably changed in a shape in different areas of cells, but varied in intensity. Comparison with the fluorescence spectra of 1-3 measured in an aqueous solution (Figure 1, Table 1) shows that intracellular spectrum of $\mathbf{2}$ has the same maximum, while spectrum maxima of $\mathbf{1}$ and 3 are blue-shifted by ca. $30 \mathrm{~nm}$, probably due to interactions of 1 and $\mathbf{3}$ with some cellular molecules. Similar blue shift of the ICT fluorescence band has been observed for the previously described 4- $\mathrm{N}, \mathrm{N}$-dimethylaminostyryl derivative in A549 cells [36].

Intracellular fluorescence spectrum of $\mathbf{1}$ excited at $405 \mathrm{~nm}$ is very wide, centered at ca. $570 \mathrm{~nm}$, and exhibit a shoulder in the $420-480 \mathrm{~nm}$ spectral range (Figure $3 \mathrm{~d}$ ). The analysis shows that this spectrum can be described as a superposition of spectra of 2 
and 3 and a residual spectrum having a maximum at $459 \mathrm{~nm}$ (Figure S26). Relative contribution of these three components into the spectrum of $\mathbf{1}$ varies in different areas of a cell (Figure S26). In the 500-700 nm spectral range, fluorescence of $\mathbf{1}$ is a superposition of oxacrown and azacrown ether moiety emissions with comparable contributions. This could be explained by an incomplete energy transfer in the compound 1 (84\%, see Section 3.1) along with the relatively high emission quantum yield of the donor chromophore: $\varphi^{\mathrm{fl}}$ value for $\mathbf{2}$ is 2.4 times higher compared with that for $\mathbf{3}$ (Table 1). Reasonably, some changes in RET efficiency and/or fluorescence quantum yields of the photoactive fragments (fluorescence quantum yields of styryl dyes exhibiting the properties of ICTfluorophores are very sensitive to the polarity of the medium [37-39]) in compound 1 may occur upon going from aqueous solution to cellular medium. For instance, RET can be hampered as a result of a specific conformation change (a decrease in RET can occur, for example, if intermolecular interactions of 1 with proteins and/or lipids lead to a fixed (or restricted) orientation of donor relative to acceptor moiety; considerably reduced RET is predicted by the Förster theory for the orientations, when an angle between the vectors of donor and acceptor transition dipole moments is close to $90^{\circ}$ [34]) or a decrease in the extent of overlap between the donor emission and acceptor absorption spectrum. The "residual" component at $459 \mathrm{~nm}$ is not related to cellular autofluorescence, because it is absent in non-treated cells and cells treated with 2 or 3 . Probably, the $459 \mathrm{~nm}$ component is a signature of particular complexes formed by $\mathbf{1}$ in cells, and this fluorescence is emitted by oxacrown moiety.

Measurement of kinetics of 1 internalization revealed that intracellular accumulation of 1 achieved saturation after 15 min of incubation of A549 cells with 1, and time of halfaccumulation was $4.0 \pm 0.2 \mathrm{~min}$ (Figure S27a). Accordingly, all the measurements of interactions between $\mathbf{1}$ and $\mathrm{Hg}^{2+}$ in cells were performed after 20 min incubation of cells with compound $\mathbf{1}$.

Compound $\mathbf{1}$ is hydrophobic, and mechanism of its intracellular penetration is supposed to be related (at least partially) to passive diffusion through plasma membrane followed by accumulation and trapping in lysosomes. It is indirectly confirmed by appearance of diffuse distribution of 1 in cytoplasm and weak staining of lysosomes 5 min after the beginning of cell incubation with dye 1 (Figure S28a). In accordance with our supposition, further incubation of cells with $\mathbf{1}$ is accompanied by an increase in lysosome accumulation of $\mathbf{1}$ as compared to its diffuse distribution (Figure S28a). One cannot exclude that endocytosis also contributes to internalization of $\mathbf{1}$, but the study of mechanisms of cellular transport of $\mathbf{1}$ is beyond the scope of this paper and requires special research.

Retention of 1 in cells was found to be long. A decrease in intensity of intracellular fluorescence of $\mathbf{1}$ or changes in the pattern of its intracellular distribution were not observed during $2.5 \mathrm{~h}$ after removal of $\mathbf{1}$ from a culture medium (Figure S27b-e).

Pre-incubation of cells with $\mathrm{Hg}\left(\mathrm{ClO}_{4}\right)_{2}$ did not change a qualitative pattern of intracellular distribution of 1 (Figure 4, Figure S29), but resulted in considerable changes in intracellular fluorescence spectra of 1 excited at $\lambda_{\mathrm{ex}}=405 \mathrm{~nm}$, thus indicating formation of (1) $\cdot \mathrm{Hg}^{2+}$ complexes (Figure $4 \mathrm{c}, \mathrm{d}$ ). At a high $\mathrm{Hg}^{2+}$ concentration, intracellular fluorescence spectrum of $1\left(\lambda_{\mathrm{ex}}=405 \mathrm{~nm}\right)$ becomes narrow and shows a maximum at $590 \mathrm{~nm}$. At $\lambda_{\mathrm{ex}}=488 \mathrm{~nm}$, intracellular spectrum of (1) $\cdot \mathrm{Hg}^{2+}$ is slightly red-shifted as compared to intracellular spectrum of $\mathbf{1}\left(\lambda_{\mathrm{ex}}=488 \mathrm{~nm}\right)$, has a maximum at $590 \mathrm{~nm}$ (Figure S29c), and coincides in shape with the spectra of $(\mathbf{1}) \cdot \mathrm{Hg}^{2+}$ complexes excited at $\lambda_{\mathrm{ex}}=405 \mathrm{~nm}$. Such changes in the emission band shape are consistent with the spectrofluorometric titration data obtained in aqueous solution (Figure 2b). As mentioned above (Section 3.2), the broadening of the short wavelength part of the emission spectrum was observed for the free ligand 1 but not for the complex (1) $\mathrm{Hg}^{2+}$. In addition, 4.8 times fluorescence enhancement occurred at $580 \mathrm{~nm}$ (Figure $2 \mathrm{~b}$ ) due to $\mathrm{Hg}^{2+}$-induced increase in the acceptor chromophore quantum yield (compare $\varphi^{\mathrm{fl}}$ values for 3 and $(3) \cdot \mathrm{Hg}^{2+}$, see Table 1 ). Similar increase in the fluorescence intensity ( $4.3 \pm 0.3$ times (calculated as the ratio of integral emission intensity in $600-730 \mathrm{~nm}$ spectral range after the addition of $50 \mu \mathrm{M}$ of $\mathrm{Hg}^{2+}$ to cells to that in the 
absence of $\left.\mathrm{Hg}^{2+}\right)$ ) also was found upon coordination of $\mathrm{Hg}^{2+}$ with $\mathbf{1}$ in cells. Obviously, the enhanced emission from the complexed $N$-chromophore in solution and in cells would lead to a low contribution of $O$-chromophore fluorescence to the overall spectrum.

I

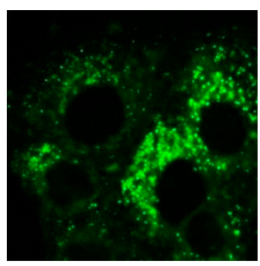

(b)

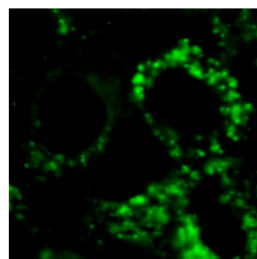

(c)

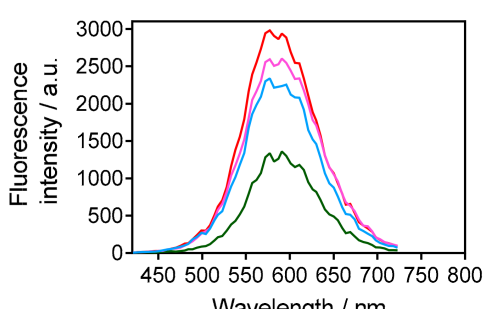

II
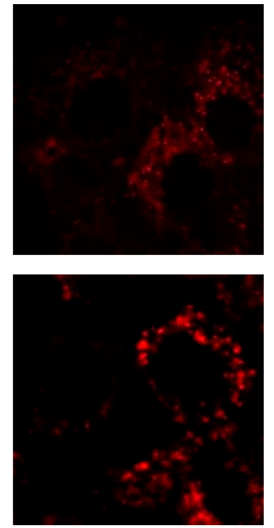

(d)
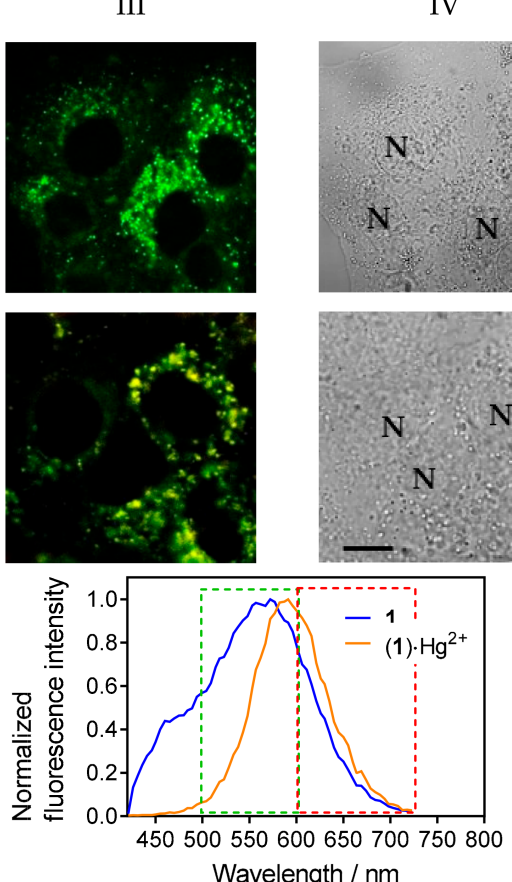

IV
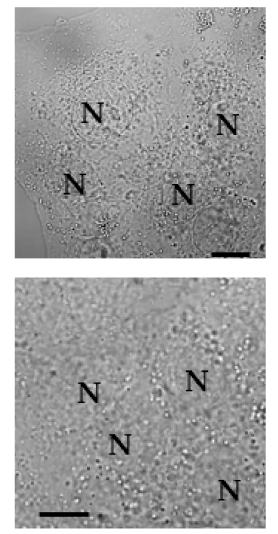

Wavelength / nm

Figure 4. Confocal fluorescence images (a,b) and fluorescence spectra (c,d) of $\mathbf{1}$ and (1) $\cdot \mathrm{Hg}^{2+}$ in A549 cells. (Row a) Cells were incubated with $\mathbf{1}(10 \mu \mathrm{M})$ for $20 \mathrm{~min}$. (Row b) Cells were pre-incubated with $20 \mu \mathrm{M} \mathrm{Hg}\left(\mathrm{ClO}_{4}\right)_{2}$ for $15 \mathrm{~min}$, washed twice with Hanks' solution, and incubated with $\mathbf{1}(10 \mu \mathrm{M})$ for $20 \mathrm{~min}$. Images of intracellular fluorescence were measured in the 500-600 nm (column I) and 600-730 nm (column II) spectral ranges at $\lambda_{\mathrm{ex}}=405 \mathrm{~nm}$. Merged fluorescent images are shown in column III. Transmitted light images of cells are shown in column IV. Bar represents $10 \mu \mathrm{m}$. N marks a nucleus. (c) Fluorescence spectra of 1 from different regions of cells pre-incubated with $\mathrm{Hg}\left(\mathrm{ClO}_{4}\right)_{2}$. (d) Typical normalized intracellular fluorescence spectra of $\mathbf{1}$ and (1) $\cdot \mathrm{Hg}^{2+}$. Green and red rectangles show two spectral regions (500-600 and 600-730 nm) selected for acquisition of images shown in columns I and II.

The observed differences in intracellular fluorescence spectra of $\mathbf{1}$ and (1) $\cdot \mathrm{Hg}^{2+}$ at $\lambda_{\mathrm{ex}}=405 \mathrm{~nm}$ can be used for a ratiometric fluorescent detection of $\mathrm{Hg}^{2+}$ in cells using compound 1. For example, measuring fluorescent images of 1 within cells in the 500-600 nm and $600-730 \mathrm{~nm}$ spectral ranges simultaneously at $\lambda_{\mathrm{ex}}=405 \mathrm{~nm}$, one can see that relative fluorescence intensities in these images are noticeably different in the presence and absence of $\mathrm{Hg}^{2+}$ ions (Figure $\left.4 \mathrm{a}, \mathrm{b}\right)$. The ratio $R$ of the fluorescence intensities $I(500-600 \mathrm{~nm}) / I$ $(600-730 \mathrm{~nm})$ calculated for and averaged over a sampling of cells $(n=20)$ is equal to $4.4 \pm 0.2$ in the absence of $\mathrm{Hg}^{2+}$ ions and $1.43 \pm 0.10$ at the saturation of $\mathrm{Hg}^{2+}$ binding to 1 . The ratio $R$ decreases as a function of $\mathrm{Hg}\left(\mathrm{ClO}_{4}\right)_{2}$ concentration added to cells (Figure 5a), indicating that $R$ is sensitive to intracellular concentration of $\mathrm{Hg}^{2+}$. A choice of two spectral ranges for an intracellular ratiometric detection of $\mathrm{Hg}^{2+}$ with compound 1 can be made in different ways. Alternatively, the 550-730 and 450-550 nm spectral ranges can be selected (Figure S33). In the last case, the ratio of fluorescence intensities $I$ $(550-730 \mathrm{~nm}) / I(450-550 \mathrm{~nm})$ varies from $1.7 \pm 0.2$ in the absence of $\mathrm{Hg}^{2+}$ ions to $4.8 \pm 0.3$ for the (1) $\cdot \mathrm{Hg}^{2+}$ complex, and complexation with $\mathrm{Hg}^{2+}$ is clearly observed in the recorded images (Figure S33). 


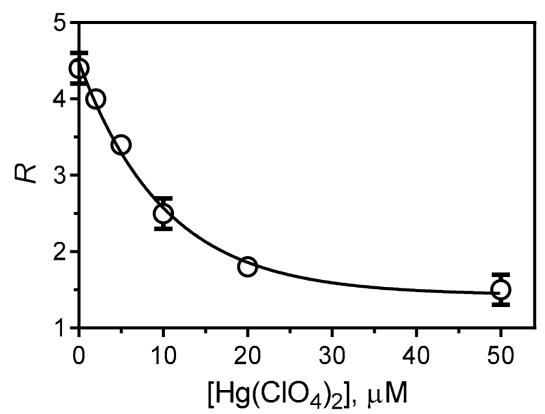

(a)

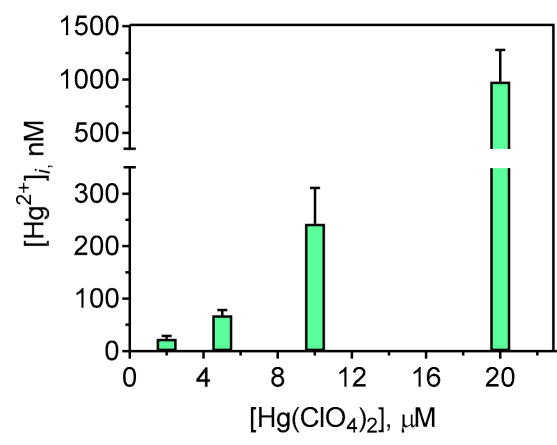

(b)

Figure 5. Detection of intracellular $\mathrm{Hg}^{2+}$ ions using a ratiometric approach with compound 1. (a) Dependence of the ratio $R$ of fluorescence intensities $I(500-600 \mathrm{~nm}) / I(600-730 \mathrm{~nm})$ on the concentration of $\mathrm{Hg}\left(\mathrm{ClO}_{4}\right)_{2}$ added to cells. Data were averaged over 20 cells in each measurement and presented as a mean $\pm \mathrm{SD}$. (b) Estimation of intracellular concentration of $\mathrm{Hg}^{2+}$ ions $\left(\left[\mathrm{Hg}^{2+}\right]_{i}\right)$ at different concentrations of $\mathrm{Hg}\left(\mathrm{ClO}_{4}\right)_{2}$ added to cells. Cells were pre-incubated with different concentrations of $\mathrm{Hg}\left(\mathrm{ClO}_{4}\right)_{2}$ for $15 \mathrm{~min}$, washed twice with Hanks' solution, incubated with $\mathbf{1}(10 \mu \mathrm{M})$ for $20 \mathrm{~min}$, and measured with CLSM.

It should be mentioned that at the direct excitation of acceptor moiety (for example, with $\lambda_{\mathrm{ex}}=488 \mathrm{~nm}$ ), intracellular fluorescence spectra of $\mathbf{1}$ and $(\mathbf{1}) \cdot \mathrm{Hg}^{2+}$ are close in shape and maxima (Figure S29), and (1) $\cdot \mathrm{Hg}^{2+}$ complex formation is mainly manifested by an increase in fluorescence intensity. At the saturation of $\mathrm{Hg}^{2+}$ binding to 1, intracellular intensity of fluorescence increases by $4.1 \pm 0.1$ times as compared to that of free $\mathbf{1}$. Therefore, alterations in intracellular fluorescence intensity of 1 at $\lambda_{\mathrm{ex}}=488 \mathrm{~nm}$ can be used (with some limitations) as an indicator of changes in intracellular concentration of $\mathrm{Hg}^{2+}$, when it is known that $\mathrm{Hg}^{2+}$ ions are present in cells. In contrast, ratiometric measurements with 1 at $\lambda_{\mathrm{ex}}=405 \mathrm{~nm}$ are applicable both for detection of $\mathrm{Hg}^{2+}$ ions in cells and measurement of changes in their concentration.

Because of weak intracellular fluorescence intensity and absence of changes in a spectrum shape, compound $\mathbf{3}$ was concluded to be not suitable for intracellular analysis of $\mathrm{Hg}^{2+}$ ions (Figure S30). Absence of changes in intracellular fluorescence spectra of 3 was observed at different incubation time of A549 cells with $\mathrm{Hg}^{2+}$ and 3 (5-30 min) in the wide range of concentrations of $\mathrm{Hg}\left(\mathrm{ClO}_{4}\right)_{2}(20-100 \mu \mathrm{M})$ and $3(5-30 \mu \mathrm{M})$. Definitely, spectral properties of 3 in cells differ considerably from those in an aqueous solution (Figure S18b), and reasons for these differences require a special study. One of the probable reasons is a basic $\mathrm{pH}(\mathrm{pH}=8.0)$ in mitochondria [40], where compound 3 is accumulated. As shown earlier [41,42], $N$-phenylazadithia-15-crown-5 ether receptor does not form stable complexes with $\mathrm{Hg}^{2+}$ at $\mathrm{pH}>7.0$ in solution, because mercury (II) ions are completely hydrolyzed at neutral and basic $\mathrm{pH}$ and exist in the form of $\mathrm{Hg}(\mathrm{OH})_{2}$ [43].

In order to verify selectivity of intracellular response of 1 to $\mathrm{Hg}^{2+}$ ions, A549 cells were pre-incubated with $\mathrm{Cu}^{2+}$ or $\mathrm{Pb}^{2+}$ ions in the concentration range of 2-1000 $\mu \mathrm{M}$, and further incubated with $\mathbf{1}(10 \mu \mathrm{M})$. No changes in either intracellular fluorescence spectra (including intensity) or a characteristic pattern of intracellular distribution of $\mathbf{1}$ were observed in the studied range of $\mathrm{Cu}^{2+}$ and $\mathrm{Pb}^{2+}$ concentrations (Figures S31 and S32). This result is in line with inability of $\mathbf{1}$ to form complexes with $\mathrm{Cu}^{2+}$ and $\mathrm{Pb}^{2+}$ in aqueous solution (see Supplementary Information, Figures S5 and S6), and let us to conclude that compound $\mathbf{1}$ is promising for selective detection of $\mathrm{Hg}^{2+}$ ions in living cells using a ratiometric approach.

Following the formalism proposed elsewhere [44], the ratiometric measurements with 1 can be used to estimate intracellular concentrations of $\mathrm{Hg}^{2+}$ ions $\left(\left[\mathrm{Hg}^{2+}\right]_{i}\right)$, as shown in the Equation (4):

$$
\left[\mathrm{Hg}^{2+}\right]_{i}=K_{d} \times Q \times \frac{R_{\max }-R}{R-R_{\min }},
$$


where $K_{d}$ is the dissociation constant of $(\mathbf{1}) \cdot \mathrm{Hg}^{2+}$ complex calculated from $\lg K$ (Table 1 ) and equal to $0.56 \pm 0.15 \mu \mathrm{M}$ (Calculated using $K$ value obtained in spectrophotometric titration experiment at $\mathrm{pH}$ 6.0. It should be noted that localization of probe $\mathbf{1}$ in lysosomes where the $\mathrm{pH}$ is more acidic (4.5-4.8) [45] would not impair the $\left[\mathrm{Hg}^{2+}\right]_{i}$ estimation. The $\lg K$ values for (1) $\cdot \mathrm{Hg}^{2+}$ complex obtained in spectrophotometric and spectrofluorometric titration experiments in $1 \times 10^{-2} \mathrm{M}$ acetate buffer at $\mathrm{pH} 4.5(6.43 \pm 0.15$ and $6.46 \pm 0.19$, respectively, see Figure S19 for titration data) were very close to those calculated at $\mathrm{pH} 6.0$ (6.27 \pm 0.12 and $6.24 \pm 0.11$, respectively, Table 1)), $R_{\max }$ and $R_{\min }$ are the $R$ values for the free ligand $1\left(R_{\max }=4.4 \pm 0.2\right)$, and for the complex $(\mathbf{1}) \cdot \mathrm{Hg}^{2+}\left(R_{\min }=1.43 \pm 0.10\right)$ in cells found using the plot in Figure $5 a, Q$ is a ratio of intracellular fluorescence intensity of the free ligand $\mathbf{1}$ to the intensity of $(\mathbf{1}) \cdot \mathrm{Hg}^{2+}$ in the $600-730 \mathrm{~nm}$ range $(Q=0.23 \pm 0.03)$.

It should be noted that the calculations of $\left[\mathrm{Hg}^{2+}\right]_{i}$ by the formula (4) allow quantification of only equilibrium concentration of the "free" mercury (II) ions. If one needs to find total amount of $\mathrm{Hg}$ (II) inside cells (including $\mathrm{Hg}$ (II) trapped in stable complexes with some species like thiol compounds), some other spectroscopic techniques such as atomic absorption spectroscopy [46] should be used. Regarding complexation with thiols, we have found that addition of a slight excess (5 equiv.) of cysteine (Cys), a model thiol compound, to a solution of complex (1) $\cdot \mathrm{Hg}^{2+}$ (obtained by mixing of $10 \mu \mathrm{M}$ dye $\mathbf{1}$ and $\left.10 \mu \mathrm{M} \mathrm{Hg}\left(\mathrm{ClO}_{4}\right)_{2}\right)$ causes a decrease in the emission intensity and changes in the absorption band shape, which are consistent with the complete release of the free ligand $\mathbf{1}$ from the complex (compare the spectrum of 1 with that of the mixture of 1 equiv. 1, 1 equiv. $\mathrm{Hg}\left(\mathrm{ClO}_{4}\right)_{2}$, and 5 equiv. Cys, Figure S34). From the spectral changes shown in Figure S34b and the known stability constant of the complex $(1) \cdot \mathrm{Hg}^{2+}(\lg K=6.27 \pm 0.12$, Table 1$)$, we estimated the $\lg \mathrm{K}$ value for the complex of $\mathrm{Hg}^{2+}$ with cysteine $\left((\mathrm{Cys}) \cdot \mathrm{Hg}^{2+}\right)$ to be as high as $6.60 \pm 0.20$. Thus, (Cys) $\cdot \mathrm{Hg}^{2+}$ and (1) $\cdot \mathrm{Hg}^{2+}$ demonstrate comparable stability. Based on this observation, we can conclude that thiol compounds present in cells (glutathione and thiol containing proteins and peptides) can bind efficiently $\mathrm{Hg}^{2+}$ ions, thereby decreasing concentration of the free $\mathrm{Hg}^{2+}$ available for complexation with 1 .

Results of $\left[\mathrm{Hg}^{2+}\right]_{i}$ estimation on the basis of $R$ values measured at different concentrations of $\mathrm{Hg}\left(\mathrm{ClO}_{4}\right)_{2}$ added to cells are shown in Figure $5 \mathrm{~b}$. The dependence of $R$ on intracellular concentration of $\mathrm{Hg}^{2+}$ in the $0-60 \mathrm{nM}$ range demonstrated a good linearity with a correlation coefficient of 0.99 (Figure S35). From the slope of this linear dependence $(r)$ and standard deviation of the ratio $R(s)$, the lower detection limit for $\mathrm{Hg}^{2+}$ in cells $\left(C_{\mathrm{DL}}\right)$ was found to be $37 \mathrm{nM}$, according to the Equation (5) [47], which is comparable with the other fluorescent $\mathrm{Hg}^{2+}$ chemosensors $[33,48]$.

$$
C_{\mathrm{DL}}=\frac{3 s}{r}
$$

As it can be seen from Figure $5 \mathrm{a}$, an increase of $\mathrm{Hg}\left(\mathrm{ClO}_{4}\right)_{2}$ concentration in extracellular medium higher than $20 \mu \mathrm{M}$ does not result in significant changes of the ratio $R$. Furthermore, the changes of $R$ at $20-50 \mu \mathrm{M} \mathrm{Hg}\left(\mathrm{ClO}_{4}\right)_{2}$ are comparable with the measurement accuracy. This means that the upper limit of $\mathrm{Hg}^{2+}$ detection inside cells with probe 1 corresponds to the presence of approximately $20 \mu \mathrm{M}$ of mercury (II) ions in the extracellular medium and, hence, appears to be $1 \mu \mathrm{M}$ (see Figure $5 \mathrm{~b}$ ). Thus, compound 1 allows quantitative detection of $\mathrm{Hg}^{2+}$ ions inside cells in the $37 \mathrm{nM}-1 \mu \mathrm{M}$ concentration range. Varying concentration of compound $\mathbf{1}$ added to cells the range of quantitative $\mathrm{Hg}^{2+}$ ion detection could be slightly extended.

Sensor 1 is not toxic to cells at the concentration of $15 \mu \mathrm{M}$ or less for $24 \mathrm{~h}$ incubation (Figure S21b), and its retention in cells is rather long (Figure S27b-e) that make this probe suitable both for quantitative detection of $\mathrm{Hg}^{2+}$ in cells and for long-term studies of $\mathrm{Hg}^{2+}$ interactions with living cells. To demonstrate it, we have used sensor $\mathbf{1}$ for evaluation of changes in intracellular concentration of $\mathrm{Hg}^{2+}$ as a function of time after removal of $\mathrm{Hg}\left(\mathrm{ClO}_{4}\right)_{2}$ from extracellular medium (Figure S36). It was found that in 30 min after removal of extracellular $10 \mu \mathrm{M} \mathrm{Hg}\left(\mathrm{ClO}_{4}\right)_{2}$, intracellular concentration of $\mathrm{Hg}^{2+}$ 
was measured to be $226 \pm 30 \mathrm{nM}$ and decreased during next 30 min to $120 \pm 20 \mathrm{nM}$ (Figure S36f), most probably because of $\mathrm{Hg}^{2+}$ efflux from cells. Interestingly, during the next $2.5 \mathrm{~h}$ intracellular concentration of $\mathrm{Hg}^{2+}$ increased to $186 \pm 30 \mathrm{nM}$ (Figure S36f), which can be explained by slow release of previously bound $\mathrm{Hg}$ (II) ions from intracellular depot.

Using Equation (4) and the plot of $R$ against $\left[\mathrm{Hg}\left(\mathrm{ClO}_{4}\right)_{2}\right]$ (Figure $5 \mathrm{a}$ ), one can estimate that the lower detection limit of intracellular $\mathrm{Hg}^{2+}(37 \mathrm{nM})$ is achieved when extracellular concentration of $\left[\mathrm{Hg}\left(\mathrm{ClO}_{4}\right)_{2}\right]$ is as low as $2.8 \mu \mathrm{M}$. The estimated value seems to be relevant in terms of sensor applications. For example, fish consumption is known to be the main contributor to the maximal allowable daily intake of $\mathrm{Hg}$ for humans. Food guidelines suggest the total mercury content of fish flesh for human consumption should generally not exceed $0.5 \mu \mathrm{g} / \mathrm{g}$ wet weight (or $2.5 \mu \mathrm{M}$ ) [49].

\section{Conclusions}

We have shown that bis(styryl) dye $\mathbf{1}$ can be applied for the visualization and ratiometric fluorescent measurement of $\mathrm{Hg}^{2+}$ concentration in living cells with good selectivity and sensitivity. Optical response of compound $\mathbf{1}$ includes an enhancement of emission intensity with a concomitant change in the shape of fluorescence spectrum and can be rationalized in terms of RET and ICT sensing mechanisms. Presented results allow us to conclude that compound $\mathbf{1}$ can find applications in the studies of the role and transformations of mercury (II) cation in complex biological systems.

Supplementary Materials: The following are available online at https:/ /www.mdpi.com/1424-822 0/21/2/470/s1, Figures S1-S36, calculations of RET efficiency in ligand $\mathbf{1}$ and complex $(\mathbf{1}) \cdot \mathrm{Hg}^{2+}$, experimental details and results concerning cell viability studies and studies on intracellular localization of 1 and 3.

Author Contributions: Conceptualization: P.A.P., A.V.F., and O.A.F.; methodology: P.A.P., A.V.F., and Y.V.F.; formal analysis: P.A.P. and A.V.E.; investigation: M.A.U. and A.V.E.; writing-original draft preparation: P.A.P. and A.V.F.; writing - review and editing: A.V.F., O.A.F., and Y.V.F.; visualization: A.V.E. and M.A.U.; supervision: A.V.F., P.A.P., and Y.V.F. P.A.P. and A.V.E. contributed equally to this paper. All authors have read and agreed to the published version of the manuscript.

Funding: The work was supported by the RFBR (Russian Foundation for Basic Research) project No 18-33-20111 (investigation of sensor properties of bis(styryl) dye $\mathbf{1}$ in living cells) and the RSCF (Russian Scientific Foundation) project No 20-73-10186 (investigation of sensor behavior of monochromophoric styryl dyes 2 and 3).

Institutional Review Board Statement: Not applicable.

Informed Consent Statement: Not applicable.

Data Availability Statement: Not applicable.

Acknowledgments: Steady-state fluorescence spectroscopy studies were performed with the financial support from Ministry of Science and Higher Education of the Russian Federation using the equipment of the Center for molecular composition studies of INEOS RAS. The research was partially performed using facilities of the Interdisciplinary Scientific and Educational School of Moscow University "Molecular Technologies of the Living Systems and Synthetic Biology".

Conflicts of Interest: The authors declare no conflict of interest.

\section{References}

1. Xu, Z.; Yoon, J.; Spring, D.R. Fluorescent chemosensors for Zn2+. Chem. Soc. Rev. 2010, 39, 1996-2006. [CrossRef] [PubMed]

2. Jeong, Y.; Yoon, J. Recent progress on fluorescent chemosensors for metal ions. Inorganica Chim. Acta 2012, 381, 2-14. [CrossRef]

3. Sivaraman, G.; Iniya, M.; Anand, T.; Kotla, N.G.; Sunnapu, O.; Singaravadivel, S.; Gulyani, A.; Chellappa, D. Chemically diverse small molecule fluorescent chemosensors for copper ion. Coord. Chem. Rev. 2018, 357, 50-104. [CrossRef]

4. Si, L.; Ariya, P.A. Recent Advances in Atmospheric Chemistry of Mercury. Atmosphere 2018, 9, 76. [CrossRef]

5. Harris, H.H.; Pickering, I.J.; George, G.N. The chemical form of mercury in fish. Science 2003, 301, 1203. [CrossRef]

6. Nendza, M.; Herbst, T.; Kussatz, C.; Gies, A. Potential for secondary poisoning and biomagnification in marine organisims. Chemosphere 1997, 35, 1875-1885. [CrossRef] 
7. Bernhoft, R.A. Mercury toxicity and treatment: A review of the literature. J. Environ. Public Health 2012, 2012. [CrossRef]

8. Magos, L.T.C. Hutchinson and K. M. Meema (Editors). Lead, Mercury, Cadmium and Arsenic in the Environment. Scope 31. John Wiley \& Sons, Chichester, 1987; 360 pp, £48.00. J. Appl. Toxicol. 1988, 8, 150-151. [CrossRef]

9. Lee, S.Y.; Bok, K.H.; Kim, C. A fluorescence "turn-on" chemosensor for Hg2+ and Ag+ based on NBD (7-nitrobenzo-2-oxa-1,3diazolyl). RSC Adv. 2017, 7, 290-299. [CrossRef]

10. Zhou, B.; Qin, S.; Chen, B.; Han, Y. A new BODIPY-based fluorescent "turn-on" probe for highly selective and rapid detection of mercury ions. Tetrahedron Lett. 2018, 59, 4359-4363. [CrossRef]

11. Lu, H.L.; Wang, W.K.; Tan, X.X.; Luo, X.F.; Zhang, M.L.; Zhang, M.; Zang, S.Q. A new quinoline-based fluorescent probe for Cd2+ and $\mathrm{Hg} 2+$ with an opposite response in a 100\% aqueous environment and live cell imaging. Dalt. Trans. 2016, 45, 8174-8181. [CrossRef] [PubMed]

12. Mu, H.; Gong, R.; Ma, Q.; Sun, Y.; Fu, E. A novel colorimetric and fluorescent chemosensor: Synthesis and selective detection for $\mathrm{Cu}^{2+}$ and $\mathrm{Hg}^{2+}$. Tetrahedron Lett. 2007, 48, 5525-5529. [CrossRef]

13. Demchenko, A.P. The concept of $\lambda$-ratiometry in fluorescence sensing and imaging. J. Fluoresc. 2010, 20, 1099-1128. [CrossRef] [PubMed]

14. Bai, J.Y.; Xie, Y.Z.; Wang, C.J.; Fang, S.Q.; Cao, L.N.; Wang, L.L.; Jin, J.Y. A Quninolylthiazole Derivatives as an ICT-Based Fluorescent Probe of $\mathrm{Hg}(\mathrm{II})$ and its Application in Ratiometric Imaging in Live HeLa Cells. J. Fluoresc. 2018, 28, 795-800. [CrossRef]

15. Wang, J.H.; Liu, Y.M.; Chao, J.B.; Wang, H.; Wang, Y.; Shuang, S.M. A simple but efficient fluorescent sensor for ratiometric sensing of Cd2+ and bio-imaging studies. Sensors Actuators, B Chem. 2020, 303, 127216. [CrossRef]

16. Zhou, Z.; Yu, M.; Yang, H.; Huang, K.; Li, F.; Yi, T.; Huang, C. FRET-based sensor for imaging chromium(III) in living cells. Chem. Commun. 2008, 3387-3389. [CrossRef]

17. Zhang, J.; Zhu, M.; Jiang, D.; Zhang, H.; Li, L.; Zhang, G.; Wang, Y.; Feng, C.; Zhao, H. A FRET-based colorimetric and ratiometric fluorescent probe for the detection of $\mathrm{Cu} 2+$ with a new trimethylindolin fluorophore. New J. Chem. 2019, 43, 10176-10182. [CrossRef]

18. Qi, D.; Zhang, J.; Zhang, D.; Zhu, M.; Gong, L.; Su, C.; Lu, W.; Bian, Y.; Jiang, J. A phthalocyanine-porphyrin triad for ratiometric fluorescent detection of Lead(II) ions. Dye. Pigment. 2020, 173, 107941. [CrossRef]

19. Prabhu, J.; Velmurugan, K.; Raman, A.; Duraipandy, N.; Kiran, M.S.; Easwaramoorthi, S.; Tang, L.; Nandhakumar, R. Pyrenephenylglycinol linked reversible ratiometric fluorescent chemosensor for the detection of aluminium in nanomolar range and its bio-imaging. Anal. Chim. Acta 2019, 1090, 114-124. [CrossRef]

20. He, X.; Xiong, W.; Lilei, Z.; Xu, C.; Fan, J.; Qian, Y.; Wen, J.; Ding, F.; Shen, J. ESIPT-based ratiometric fluorescent probe for highly selective and sensitive sensing and bioimaging of group IIIA ions in living cancer cells and zebrafish. Dye. Pigment. 2020, 174, 108059. [CrossRef]

21. Zhang, X.; Xiao, Y.; Qian, X. A ratiometric fluorescent probe based on FRET for imaging $\mathrm{Hg}^{2+}$ ions in living cells. Angew. Chem. Int. Ed. 2008, 47, 8025-8029. [CrossRef] [PubMed]

22. Singh, G.; Reja, S.I.; Bhalla, V.; Kaur, D.; Kaur, P.; Arora, S.; Kumar, M. Hexaphenylbenzene appended AIEE active FRET based fluorescent probe for selective imaging of $\mathrm{Hg}^{2+}$ ions in MCF-7 cell lines. Sens. Actuators B Chem. 2017, 249, 311-320. [CrossRef]

23. Li, Y.; Qi, S.; Xia, C.; Xu, Y.; Duan, G.; Ge, Y. A FRET ratiometric fluorescent probe for detection of Hg2+ based on an imidazo[1,2a]pyridine-rhodamine system. Anal. Chim. Acta 2019, 1077, 243-248. [CrossRef] [PubMed]

24. Berdnikova, D.V.; Fedorov, Y.V.; Fedorova, O.A.; Jonusauskas, G. Supramolecular tuning of energy transfer efficiency and direction in a bis(styryl) dye-crown ether conjugate. Dye. Pigment. 2018, 151, 227-232. [CrossRef]

25. Ustimova, M.A.; Lebedeva, A.Y.; Fedorov, Y.V.; Berdnikova, D.V.; Fedorova, O.A. FRET-based metal ion sensing by a crowncontaining bisstyryl dye. New J. Chem. 2018, 42, 7908-7913. [CrossRef]

26. Tulyakova, E.V.; Fedorova, O.A.; Fedorov, Y.V.; Jonusauskas, G.; Anisimov, A.V. Effect of arrangement of the styryl fragment on the optical properties and complexation of mono-and bis(styryl)-substituted N-methylpyridinium perchlorates containing benzo-15-crown-5 ether moieties. Russ. Chem. Bull. 2007, 56, 2166-2174. [CrossRef]

27. Tulyakova, E.V.; Fedorova, O.A.; Fedorov, Y.V.; Jonusauskas, G.; Anisimov, A.V. Spectroscopic study of mono- and bis(styryl) dyes of the pyridinium series containing azathiacrown ether residue. J. Phys. Org. Chem. 2008, 21, 372-380. [CrossRef]

28. Nad, S.; Kumbhakar, M.; Pal, H. Photophysical properties of coumarin-152 and coumarin-481 dyes: Unusual behavior in nonpolar and in higher polarity solvents. J. Phys. Chem. A 2003, 107, 4808-4816. [CrossRef]

29. Connors, K.A. Binding constants: The measurement of molecular complex stability. Eur. J. Med. Chem. 1987, 22, 373. [CrossRef]

30. Beck, M.T.; Nagypál, I. Chemistry of Complex Equilibria; John Wiley \& Sons: New York, NY, USA, 1990.

31. Hou, H.; Zhao, Y.; Li, C.; Wang, M.; Xu, X.; Jin, Y. Single-cell pH imaging and detection for pH profiling and label-free rapid identification of cancer-cells. Sci. Rep. 2017, 7, 1-8. [CrossRef]

32. Selektor, S.L.; Bogdanova, L.B.; Shokurov, A.V.; Panchenko, P.A.; Fedorova, O.A.; Arslanov, V.V. Intra- and interlayer energy transfer in planar systems based on amphiphilic naphthalimide derivatives. Macroheterocycles 2014, 7, 311-320. [CrossRef]

33. Panchenko, P.A.; Fedorov, Y.V.; Fedorova, O.A. Selective fluorometric sensing of $\mathrm{Hg} 2+$ in aqueous solution by the inhibition of PET from dithia-15-crown-5 ether receptor conjugated to 4-amino-1,8-naphthalimide fluorophore. J. Photochem. Photobiol. A Chem. 2018, 364, 124-129. [CrossRef] 
34. Lakowicz, J.R. Principles of Fluorescence Spectroscopy; Springer Science + Business Media, LLC: New York, NY, USA, 2006; ISBN 0387312781.

35. Efremenko, A.V.; Ignatova, A.A.; Grin, M.A.; Sivaev, I.B.; Mironov, A.F.; Bregadze, V.I.; Feofanov, A.V. Chlorin e6 fused with a cobalt-bis(dicarbollide) nanoparticle provides efficient boron delivery and photoinduced cytotoxicity in cancer cells. Photochem. Photobiol. Sci. 2014, 13, 92-102. [CrossRef] [PubMed]

36. Panchenko, P.A.; Grin, M.A.; Fedorova, O.A.; Zakharko, M.A.; Pritmov, D.A.; Mironov, A.F.; Arkhipova, A.N.; Fedorov, Y.V.; Jonusauskas, G.; Yakubovskaya, R.I.; et al. A novel bacteriochlorin-styrylnaphthalimide conjugate for simultaneous photodynamic therapy and fluorescence imaging. Phys. Chem. Chem. Phys. 2017, 19, 30195-30206. [CrossRef] [PubMed]

37. Jedrzejewska, B.; Kabatc, J.; Paczkowski, J. 1,3-Bis[4-(p-aminostyryl)-pyridinyl]-propane dibromide derivatives: Synthesis and spectroscopic investigation. Dyes Pigments 2007, 73, 361-367. [CrossRef]

38. Panchenko, P.A.; Arkhipova, A.N.; Fedorova, O.A.; Fedorov, Y.V.; Zakharko, M.A.; Arkhipov, D.E.; Jonusauskas, G. Controlling photophysics of styrylnaphthalimides through TICT, fluorescence and: E, Z-photoisomerization interplay. Phys. Chem. Chem. Phys. 2017, 19, 1244-1256. [CrossRef]

39. Beltrán, A.; Burguete, M.I.; Luis, S.V.; Galindo, F. Styrylpyrylium Dyes as Solvent-Sensitive Molecules Displaying Dual Fluorescence. Eur. J. Org. Chem. 2017, 2017, 4864-4870. [CrossRef]

40. Nolan, D.P.; Voorheis, H.P. Hydrogen ion gradients across the mitochondrial, endosomal and plasma membranes in bloodstream forms of Trypanosoma brucei. Eur. J. Biochem. 2000, 267, 4601-4614. [CrossRef]

41. Park, C.S.; Lee, J.Y.; Kang, E.J.; Lee, J.E.; Lee, S.S. A highly selective fluorescent chemosensor for silver(I) in water/ethanol mixture. Tetrahedron Lett. 2009, 50, 671-675. [CrossRef]

42. Panchenko, P.A.; Polyakova, A.S.; Fedorov, Y.V.; Fedorova, O.A. Chemoselective detection of Ag + in purely aqueous solution using fluorescence 'turn-on' probe based on crown-containing 4-methoxy-1,8-naphthalimide. Mendeleev Commun. 2019, 29, 155-157. [CrossRef]

43. Walcarius, A.; Etienne, M.; Delacote, C. Uptake of inorganic HgII by organically modified silicates: Influence of pH and chloride concentration on the binding pathways and electrochemical monitoring of the processes. Anal. Chim. Acta 2004, 508, 87-98. [CrossRef]

44. Grynkiewicz, G.; Poenie, M.; Tsien, R.Y. A new generation of $\mathrm{Ca}^{2+}$ indicators with greatly improved fluorescence properties. J. Biol. Chem. 1985, 260, 3440-3450. [CrossRef]

45. Ohkuma, S.; Poole, B. Fluorescence probe measurement of the intralysosomal $\mathrm{pH}$ in living cells and the perturbation of $\mathrm{pH}$ by various agents. PNAS 1978, 75, 3327-3331. [CrossRef] [PubMed]

46. Yoshimoto, K.; Thi Van Anh, H.; Yamamoto, A.; Koriyama, C.; Ishibashi, Y.; Tabata, M.; Nakano, A.; Yamamoto, M. Simple analysis of total mercury and methylmercury in seafood using heating vaporization atomic absorption spectrometry. J. Toxicol. Sci. 2016, 41, 489-500. [CrossRef]

47. Loock, H.P.; Wentzell, P.D. Detection limits of chemical sensors: Applications and misapplications. Sens. Actuators B Chem. 2012, 173, 157-163. [CrossRef]

48. Zhao, M.; Shao, G.-K.; Guo, Y.-S.; Tang, Y.-L.; Liu, J.-B.; Guo, D.-S. A reaction-type receptor for the multi-feature detection of Hg ${ }^{2+}$ in water and living cells. New J. Chem. 2020, 44, 12538-12545. [CrossRef]

49. Hoyle, I.; Handy, R.D. Dose-dependent inorganic mercury absorption by isolated perfused intestine of rainbow trout, Oncorhynchus mykiss, involves both amiloride-sensitive and energy-dependent pathways. Aquat. Toxicol. 2005, 72, 147-159. [CrossRef] 